\title{
Firm Value Improvement Strategy, Corporate Social Responsibility, and Institutional Ownership
}

\author{
M. Chabachib ${ }^{1}$, Tyana Ulfa Fitriana ${ }^{1}$, Hersugondo Hersugondo ${ }^{1}$, Imang Dapit Pamungkas ${ }^{2} \&$ Udin $_{\text {Udin }}{ }^{1}$ \\ ${ }^{1}$ Business and Economics Faculty, Diponegoro University, Semarang, Indonesia \\ ${ }^{2}$ Business and Economics Faculty, Dian Nuswantoro University, Semarang, Indonesia \\ Correspondence: Udin Udin, Business and Economics Faculty, Diponegoro University, Semarang, Indonesia.
}

Received: July 1, 2019

Accepted: July 17, 2019

Online Published: July 23, 2019

doi:10.5430/ijfr.v10n4p152

URL: https://doi.org/10.5430/ijfr.v10n4p152

\begin{abstract}
The study is intended to appraise return on assets (ROA), debt/equity ratio (DER), and firm size (SIZE) on price-to-book-value (PBV) with corporate social responsibility as an intervening variable and institutional proprietorship as a moderating variable. By using purposive sampling, 267 manufacturing companies are determined from the Indonesia Stock Exchange in the period of 2013-2017. Data are analyzed using multiple and bivariate regression analysis. The results show that ROA and firm size have a positive effect on corporate society awareness, while DER has no significant effect respectively. Profit gain, firm scope, and corporate social responsibility have a positive effect on firm utility. It came into a conclusion that corporate social awareness can be used to mediate the influence on leverage and firm scope toward the firm value, but cannot be used to mediate the effect of profit gain on firm utility.
\end{abstract}

Keywords: firm value, corporate social responsibility, institutional ownership

\section{Introduction}

It is a must that a company to be able to improve welfare for employees, managers, shareholders, related parties and society. Consequently, every company must also have different perspectives and patterns of thinking in determining the steps or strategies that will be used as a tool in achieving company goals. The crucial company goals are increasing its profits and firm value for the welfare of owners and related parties. In this progressively advanced era, companies are increasingly trying to maintain their business excellence so that their corporate value increases. With high corporate value, it will improve the welfare of shareholders. With these welfare guarantees, shareholders will not hesitate to invest their capital. The company's financial performance can be seen with profitability ratios. The profitability ratio is used to assess the operational effectiveness of the company. The better the company's operational performance, the more it increases the value of the company (Brimingham and Houston, 2001). The higher the value of Return on Assets (ROA), the higher the efficiency of the company will be, and the greater the chance for the company to increase its value.

In determining the value of the enterprise, the size of the firm or entire assets factors needs to be considered. Because the greater the total assets owned by the company, the use of company assets is more freely used by management. Even so, the management has the freedom that is comparable to the concern made by the owner of his assets. If assessed from the side of the company owner, the large number of assets actually makes the value of the company decrease. However, if assessed from the management side, the ease of controlling the company will increase the value of the company (Sari, 2016). Leverage is a way to measure how much the company has a risk level of uncollectible debt to creditors who will later be used to finance company assets. In this study using the proxy Debt to Equity Ratio (DER) to measure the debt comparative level.

The role of Corporate Social Responsibility (CSR) is very important for companies, especially for companies that carry out their activities in fields related to natural resources. Because according to the Limited Liability Company Law No. 40 of 2007 article 74 (www.bapepam.go.id). Decision of the Head of the Capital Supervisory Agency (KBPM) and Financial Institution No. KEP-134 / BL / 2006 requires public companies to submit their annual reports which contain an explanation of the activities and costs used in social and environmental responsibility activities. Corporate Social Responsibility is one aspect that can consider its influence in maximizing firm value. Disclosure of 
CSR can increase firm value because of theory stakeholders emphasize that companies must disclose information CSR activities as a form of corporate responsibility towards parties stakeholders affected by the existence of the company (Chairiri and Ghozali, 2007).

Agency theory explains that conflict can be overcome by the mechanism of Good Corporate Governance, one of which is the internal mechanism, namely institutional ownership. Institutional ownership can reduce agency conflict because, in company activities, the institution will supervise management, so that it minimizes earnings management. With institutional ownership, the company's performance will be better maintained so that the relationship between managers and capital providers can be maintained.

Table 1. Research gap

\begin{tabular}{|c|c|c|c|}
\hline Dependent & Independent & Relationship & Researcher \\
\hline \multirow{19}{*}{ CSR } & \multirow{6}{*}{ Profitability } & \multirow{3}{*}{ (+) Significant } & Dewi \& Wirawati (2018) \\
\hline & & & Swandari \& Sadikin (2016) \\
\hline & & & Rindawati (2015) \\
\hline & & \multirow{3}{*}{ (-) Significant } & Maiyarni et al.,(2014) \\
\hline & & & Rofiqkoh (2016) \\
\hline & & & Ratna \& Bagus (2016) \\
\hline & \multirow{4}{*}{ Size } & (+) Significant & Ratna \& Bagus (2016) \\
\hline & & \multirow{2}{*}{ (-) Significant } & Swandari \& Sadikin (2016) \\
\hline & & & Rindawati (2015) \\
\hline & & Not Significant & Maiyarni et al., (2014) \\
\hline & \multirow{6}{*}{ Leverage } & (+) Significant & Purnasiwi (2010) \\
\hline & & \multirow{4}{*}{ (-) Significant } & Erwati (2014) \\
\hline & & & Swandari \& Sadikin (2016) \\
\hline & & & Ratna \& Bagus (2016) \\
\hline & & & Rindawati (2015) \\
\hline & & Not Significant & Isnaini (2017) \\
\hline & \multirow{3}{*}{$\begin{array}{l}\text { Institutional } \\
\text { Ownership }\end{array}$} & \multirow{2}{*}{ (+) Significant } & Elvina et al.,(2016) \\
\hline & & & Zulvina et al., (2017) \\
\hline & & (-) Significant & Swandari \& Sadikin (2016) \\
\hline \multirow{12}{*}{ Firm Value } & \multirow{3}{*}{ CSR } & (+) Significant & Ayu \& Suarjaya (2017) \\
\hline & & (-) Significant & Ratna \& Bagus (2016) \\
\hline & & Not Significant & Dewi \& Wirawati (2018) \\
\hline & \multirow{4}{*}{ Profitability } & (+) Significant & Dewi \& Wirawati (2018) \\
\hline & & \multirow{2}{*}{ (-) Significant } & Triagustina (2015) \\
\hline & & & Ratna \& Bagus (2016) \\
\hline & & Not Significant & Khumairoh et al.,(2016) \\
\hline & \multirow{4}{*}{ Firm Size } & \multirow{2}{*}{ (+) Significant } & Pramana \& Mustanda (2016) \\
\hline & & & Khumairoh et al., (2016) \\
\hline & & (-) Significant & Rambe \& Torong (2014) \\
\hline & & Not Significant & Nurminda et al.,(2017) \\
\hline & Leverage & (+) Significant & Wihardjo (2014) \\
\hline
\end{tabular}




\begin{tabular}{lll}
\hline & & Khumairoh et al.,(2016) \\
\cline { 3 - 3 } & & Putri (2016) \\
\cline { 3 - 3 } & & Ogolmagai (2013) \\
\cline { 3 - 3 } & & Nurminda et al.,(2017) \\
\cline { 3 - 3 } & Not Significant & Ratna \& Bagus (2016) \\
Onstitutional & (+) Significant & Farshid et al., (2014) \\
\cline { 2 - 3 } & (-) Significant & Elva Nuraina (2012) \\
\cline { 2 - 3 } & Not Significant & Wahyudi dan Pawestri (2006) \\
\hline
\end{tabular}

Source: various journals published

Based on data from inconsistent phenomena and research gaps that have been summarized among variables, namely profitability, size, leverage, and institutional ownership of CSR, the value of the company is inconsistent, so further research is essential. The objectives of this study are as follows: (1) Analyzing the effect of profitability (ROA), size, leverage (DER) and Corporate Social Responsibility (CSR) on firm value (PBV). (2) Analyzing the impact of profitability (ROA), size, leverage (DER) and institutional ownership on Corporate Social Responsibility (CSR). (3) Analyzing the impact of profit gain (ROA) in Corporate Social Responsibility (CSR) after being influenced by moderating variables, namely institutional ownership. (4) Analyzing the effect of profitability (ROA) on firm value after being influenced by the moderating variable namely institutional ownership. (5) Analyzing the effect of profitability (ROA), size, leverage (DER) on firm value (PBV) after being influenced by the corporation awareness towards society $(\mathrm{CSR})$ as an intercede variable.

\section{Theoretical Framework and Hypotheses}

Legitimacy is a psychological condition that states the partiality of people and groups who are very sensitive to the symptoms of the surrounding environment, both physical and non-physical (Hadi, 2011). Legitimacy can be obtained if there is a match between the existence of a company and the existence of a value system that exists in society and the environment. The legitimacy of the company will be threatened if there is a shift towards nonconformity (Deegan and Tobin, 2002). Therefore, in the eyes of stakeholders, significant factors to support the company's image and reputation are corporate legitimacy (Hadi, 2011). Thus, the disclosure of information on Corporate Social Responsibility (CSR) can be applied as a foundation for the construction of enterprise strategy. Moreover, the long-term investment and the disclosure of CSR information has benefits in improving image and legitimacy.

According to The World Business Council for Sustainable Development (WBCSD), CSR is a business dedication contributing to sustainable economic development, by collaborating their employees, families, communities and the general public to upgrade the quality of life. There are laws which regulate corporate awareness towards society in Indonesia and they are the Limited Liability Company Law No.40 of 2007 article 74, and Law No.19 of 2003 concerning SOEs are then elaborated in more detail by Minister of BUMN State Regulation No.4 of 2007 which administered the CSR starting from the number of funds to the procedures for implementation. The level of disclosure of information on corporate social responsibility assessed through the activities carried out by 7 companies was then measured using the Global Reporting Initiative (GRI). This is an organization-based network that has introduced the development of the world, using mostly the framework of the sustainability report and is performed to continue making improvements and implementations throughout the world (www.globalreporting.org).

The declaration of CSR activities is a good cue for investors and stakeholders showing that the company is active in implementing CSR activities, and the company's market value is in a good position. A good corporate social performance assists the company to gain a reputation from the capital and tally market so as to make the value of a company increase. Signal theory states that the company's executives have more knowledge of the enterprise. This shall encourage companies to transfer this knowledge to prospective investors so that the company's stock price shall increases. If profitability increases, the company is increasingly active in expressing social responsibility and the environment. Dewi and Wirawati (2018) stated that the high level of company profitability was due to good performance achievements which would have an impact on the increasing measures of the company's resources 
where the company would get a lot of public attention. The company will make CSR disclosures more broadly so that the existence of the company can be accepted by stakeholders in order to make sure the survival of the enterprise and obtain greater profits in the future. Recent empirical evidence shows that companies with good ratings on material sustainability CSR issues significantly outperform companies with a poor rating on sustainability issues (Khan et al., 2016; Rezaee et al., 2019).

Based on agency theory, the greater the agency costs owned by large companies, the wider the disclosure of information is implemented to minimize the organization's spend. In addition, big enterprises are issuers that are widely highlighted, a bigger revelation is a reduction in political costs as a manifestation of corporate social responsibility (Sembiring, 2005). Cowen et al., (1987) suggest that large companies may have shareholders who focusing on social programs created by the enterprise in annual reports, which are media to disseminate information about social enterprise responsibility. CSR is a shape of social responsibility carried out by the company to all stakeholders in the social and environmental environment in matters relating to the company's operational activities. Presently the company is not only faced with a form of single bottom line responsibility, which is only on financial responsibility but also demanded on the triple bottom line responsibility. All of which has its responsibility on the financial, environmental and social dimensions. CSR plays an important role in connecting consumers with socially responsible companies, and loyal consumers are willing to pay higher prices for goods and services provided by the company, which in turn positively affects the value of company (Chang et al., 2019; Lev et al., 2010; Servaes and Tamayo, 2013).

According to legitimacy theory, companies should provide disclosure of social activities to ensure the survival of the enterprise and the actuality of the organization can be accepted by society. If the company has a good image in the community, consumers will be interested in using the product. Firm value is a reference for investors regarding interest in investing. Firm value is seen from stock prices and company profits as a result of investors investing in the company. With companies conducting CSR activities, companies can give a good image to companies to external parties. In addition, the company can also maximize shareholder capital, corporate reputation and the long-drawn sustainability of the organization. With support from the environment in the company, the company will also get a good reputation and existence and will raise the rate of the enterprise. CSR is an element that is considered to raise the value of the related enterprise.

Based on signaling theory, the size of the company is interpreted as a positive signal received by investors that the company has good prospects. Khumairoh et al., (2016) explained that if the size of the company is getting bigger, the company will find it easier to obtain internal and external funding sources. According to agent theory, agency conflict arises because of the separation between ownership and management of the company. This is because principals and agents have conflicting interests with each other, where principals and agents try to maximize their utility. Corporate Social Responsibility is one way to bolster the relationship between the company and stakeholders because it is a form of balance between economic, environmental and community interests. In agency theory, managers as agents have a responsibility to principals to disclose CSR as a form of corporate social responsibility.

Institutional ownership is a company proprietorship that shares by institutions or organization outside the company. This such organizational proprietorship is presumed to be a successful observing system in every resolution done by the manager. An elevated degree of organizational proprietorship will lead to bigger monitoring measures done by organizational investors so that it creates hinder on manager's practical behavior. Institutional ownership has a strong motivation to carry out tighter supervision of activities that occur within the company. Because the main task of management is to prosper the owners of capital, with the existence of institutional ownership that strictly controls the activities of the company will help management efforts to maximize the value of the company. Therefore, high institutional ownership will strengthen the effect of CSR on Firm value. The company executes many CSR activities based on the profits obtained by the company. The more profit the company gets, the more CSR activities the company does, and vice versa. So, when a company tries to boost CSR activities, the company is more likely to get a CSR Award. If the company wins the CSR Award, the information should be well responded to investors. Where the response is in the form of increased stock prices and increased stock trading volume as well. In this regard, investors will think that the company that won the award has carried out CSR activities to the maximum extent possible. That is what will affect the stock price, where the stock price is a reflection of the value of the company.

Leverage is proxied by DER (Debt to Equity Ratio), the higher the level of the leverage ratio, the more likely the company will violate the debt agreement so that the company will attempt to report higher current profits. In order for reported profits to be high, managers must reduce costs, including costs incurred to disclose social information (CSR). CSR presents social information carried out by the company which investors will later respond to. The 
response given by investors can affect the volume of stock trading for companies while the products produced by companies that implement CSR will also be favored by consumers so that company profits will increase. Therefore, if CSR practices are implemented properly, it is expected that the company will be valued properly by investors.

Based on signaling theory, when profitability decreases the price Company shares also declined as a result of the signal accepted by investors that the company does not promise good prospects in the future front, thus affecting the rate of the organization. The bigger the scope or scale of the enterprise, the easier it will be for the enterprise to collect funding sources both internally and externally. In addition, large companies are considered to be relatively more stable in producing profits so that they attract investors (Chen and Shun, 2011). This is in accordance with agency theory, where large companies are having bigger agency's costs which will reveal more extensive information to reduce agency's spend including Corporate CSR. Besides that large companies are issuers that are highlighted a lot, the disclosure of greater is a reduction in political costs as a form of corporate social responsibility (Sembiring, 2005). Sembiring (2005) states that larger companies with high operating activities and greater influence on society will have shareholders who may be focusing to social programs made by the organization, therefore annual reports will be used to disseminate information about social responsibility company.

According to the theory of social legitimacy that companies have contracts with the community to carry out their activities based on the values of justice, and how companies respond to various interest groups to legitimize company actions (Haniffa et al., 2005). Further emphasizes that CSR influences investors' valuation besides the size of the company that promises a stable stock return. The larger the capacity of the company, the greater the pressure and responsibility for stakeholders would be. From the theoretical foundation, research gap, and gap phenomena, the alternative research hypothesis can be concluded as follows:

H1: ROA has a positive effect on CSR.

H2: Size has a positive effect on CSR.

H3: Leverage has a negative effect on CSR.

H4: CSR has a positive effect on PBV.

H5: ROA has a positive effect on PBV.

H6: Size has a positive effect on PBV.

H7: Leverage has a negative effect on PBV.

H8: Institutional proprietorship moderates the relationship between CSR and firm value.

H9: Institutional proprietorship moderates the relationship between profit gain and firm value.

H10: CSR mediates the relationship between profit gain and firm value.

H11: CSR mediates the relationship between leverage and firm value.

H12: CSR mediates the relationship between firm size and firm value.

\section{Methods}

\subsection{Data Collection and Sample}

The information gathering method used in this study is documentation method by recording and copying data obtained from Bloomberg site and manufacturing company's annual financial reports on the period of 2013-2017 contained in the Indonesia Stock Exchange.

Table 2. Operational definition of variables

\begin{tabular}{|c|c|c|c|c|}
\hline Variable & Proxy & Information & Formula & Scale \\
\hline $\begin{array}{l}\text { Price to Book } \\
\text { Ratio }\end{array}$ & PBV & $\begin{array}{l}\text { Calculation of firm value by } \\
\text { dividing the value of shares by } \\
\text { the book value of the company }\end{array}$ & $\frac{\text { Company Market Value }}{\text { Book Value of the Company }}$ & Rasio \\
\hline $\begin{array}{l}\text { Return } \\
\text { Asset }\end{array}$ & ROA & $\begin{array}{l}\text { ROA is being taken to estimate } \\
\text { the capability of the } \\
\text { management of the enterprise } \\
\text { to obtain profits (profits) as a }\end{array}$ & $\frac{\text { Earning before tax }}{\text { Total company assets }}$ & Rasio \\
\hline
\end{tabular}




\begin{tabular}{|c|c|c|c|c|}
\hline & & whole & & \\
\hline Firm Size & SIZE & $\begin{array}{l}\text { Firm size is measured using } \\
\text { total assets }\end{array}$ & Total Company Assets & Rupiah \\
\hline $\begin{array}{l}\text { Debt to Equity } \\
\text { Ratio }\end{array}$ & DER & $\begin{array}{l}\text { Debt Equity Ratio (DER) is the } \\
\text { calculation in comparing debt } \\
\text { and capital to measure the size } \\
\text { of the ratio }\end{array}$ & $\frac{\text { Total debt }}{\text { total equity }}$ & Rasio \\
\hline $\begin{array}{l}\text { Institutional } \\
\text { Ownership }\end{array}$ & INST & $\begin{array}{l}\text { Total shares owned by a } \\
\text { company by another institution } \\
\text { in one year }\end{array}$ & $\begin{array}{l}\text { Number of institutional shares } \\
\text { Number of shares outstanding }\end{array}$ & Rasio \\
\hline $\begin{array}{l}\text { Corporate } \\
\text { Social } \\
\text { Responsibility }\end{array}$ & $\mathrm{CSRD}_{\mathrm{I}}$ & $\begin{array}{l}\text { An activity or plan } \\
\text { implemented by the company } \\
\text { (based on the capability of the } \\
\text { company) } \\
\text { as a part of their awareness } \\
\text { toward society/environment } \\
\text { surrounding the company }\end{array}$ & $C S R D i=\frac{\sum X y i}{n i}$ & Score \\
\hline
\end{tabular}

Table 3. Number of samples

\begin{tabular}{ll}
\hline Criteria & Number of Samples \\
\hline Total population & 144 \\
\hline Manufacturing companies listed on the IDX in a row during the period 2013-2017. & 127 \\
\hline $\begin{array}{l}\text { Manufacturing companies that publish annual financial reports with Rupiah during the } \\
\text { period 2013 - 2017. }\end{array}$ & 97 \\
\hline $\begin{array}{l}\text { Manufacturing companies that publish sustainability reports or other social information } \\
\text { in succession during the period of 2013-2017. }\end{array}$ & 60 \\
\hline Number of Samples & 300 \\
\hline
\end{tabular}

Preliminary data from this study were 300 data. However, after eliminating 33 data on the data that was considered has extreme values, the observational data now amounts to 267 data considered free of outliers and worthy of processing in research.

Table 4. Descriptive statistics research variables

\begin{tabular}{llllll}
\hline & N & Minimum & Maximum & Mean & Std. Deviation \\
\hline ROA & 267 & $-0,27$ & 0,58 & 0,11 & 0,12 \\
\hline DER & 267 & 0,00 & 0,81 & 0,12 & 0,13 \\
\hline SIZE & 267 & 23,3 & 33,2 & 28,19 & 1,65 \\
\hline CSR & 267 & 0,03 & 0,33 & 0,15 & 0,06 \\
\hline PBV & 267 & $-2,12$ & 4,14 & 0,43 & 1,17 \\
\hline INST & 267 & 0,11 & 3,23 & 0,66 & 0,37 \\
\hline Valid N (listwise) & 267 & & & & \\
\hline
\end{tabular}

Source: Secondary data processed, 2018

In Table 4 provides information that the number of outlier free data and feasible to use in this study are as many as 267 data on a manufacturing company listed on the IDX for the period 2013 - 2017. 
Table 5. Coefficient of determination test $\left(\mathrm{R}^{2}\right)$

\begin{tabular}{lllll}
\hline Model & R & R Square & Adjusted R Square & Std. Error of the Estimate \\
\hline 1 &, $429^{\text {a }}$ &, 184 &, 168 &, 060801945 \\
\hline
\end{tabular}

a. Predictor: (Constant), ROA, DER, SIZE, INST, ROA. INST

b. Dependent variable: CSR

From Table 5 it can be seen that the adjusted $\mathrm{R}$ square value is 0.168 or $16.8 \%$. Therefore it can be analyzed that $16.8 \%$ of CSR variables can be described by the independent variables ROA, DER, and SIZE with the rest of $83.2 \%$ is described by other variables outside the research model.

Table 6. Partial test results (t-Test)

\begin{tabular}{|c|c|c|c|c|c|c|}
\hline \multicolumn{2}{|c|}{ Model } & \multicolumn{2}{|c|}{ Unstandardized Coefficients } & $\begin{array}{l}\text { Standardized } \\
\text { Coefficients } \\
\text { Beta }\end{array}$ & $\mathbf{t}$ & Sig. \\
\hline \multirow[t]{7}{*}{1} & (Constant) & $-4,707$ & ,751 & & $-6,265$ & ,000 \\
\hline & ROA & 6,476 & ,364 & 671 & 17,794 & ,000 \\
\hline & DER &,- 194 & ,551 &,- 021 &,- 352 & ,725 \\
\hline & SIZE & ,158 & ,027 & ,219 & 5,773 & ,000 \\
\hline & INST &,- 088 & ,139 &,- 028 &,- 627 & ,531 \\
\hline & ROA.INST &, 065 &, 033 &, 086 & 1,985 & ,048 \\
\hline & CSR & 1,969 & ,680 & ,112 & 2,896 & ,004 \\
\hline
\end{tabular}

a. Dependent Variable: PBV

\subsection{Path Analysis}

Path analysis is used to test intervening variables and moderating variables in this study. According to Ghozali (2011) Path analysis is an extension of the regression analysis used to estimate causality between variables (casual types) that previously been classified based on the theory. Besides that, path analysis cannot be used to determine causal relationships and also cannot be used as a substitution to see causality between variables. This method can only be used to determine the pattern of relationships among three or more variables and not to accepting or reject the imaginary causality hypothesis (Ghozali, 2011).

The path diagram shows explicitly the causality between variable based on theory. In the preparation of path diagrams, the relationship between variables is indicated by one arrow. Every p-value reflects paths and path coefficients. The diagram above can be explained that variable $\mathrm{X}$ has a direct relationship to variable $\mathrm{Y}$. But the variable $\mathrm{X}$ indirectly also has a relationship with the variable $\mathrm{Y}$ through the intermediary of variable $\mathrm{M}$. The direct relationship means nothing variable that mediates the relationship between the two variables. Whereas relationships indirectly mean there is a third variable that connects or mediate between the two variables. This study uses intervening variables that profitability proxied by ROE. Path analysis is used to analyze strength construct among variables for indirect, direct and total influence independent variable on the dependent variable. Path analysis in this study presented as follows: 


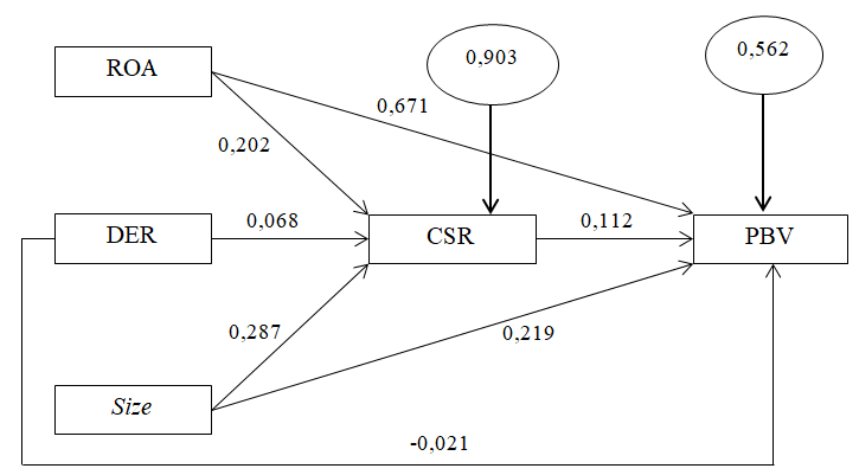

Figure 1. Path analysis of the effect of PBV with CSR as intervening variables

\section{Discussion}

From Figure 1 can be seen the results of multiple linear regression analysis. The value of beta standardized coefficients and values is obtained error obtained from the calculation $\sqrt{ }\left(\left(1-\mathrm{R}^{\wedge} 2\right)\right)$ of each equation. The value will then be used to examine the direct and indirect connection among independent variables on the dependent variable.

Table 7. Summary of hypothesis tests

\begin{tabular}{lll}
\hline Hypotheses & Result & Conclusion \\
\hline ROA has a positive effect on CSR & Significant & Accepted \\
\hline DER has a positive effect on CSR & Not significant & Rejected \\
\hline SIZE has a positive effect on CSR & Significant & Accepted \\
\hline CSR has a positive effect on PBV & Significant & Accepted \\
\hline ROA has a positive effect on PBV & Significant & Accepted \\
\hline DER has a negative effect on PBV & Not significant & Rejected \\
\hline SIZE has a positive effect on PBV & Significant & Accepted \\
\hline Institutional ownership does not moderate the impact of ROA on CSR & Not moderate & Rejected \\
\hline Institutional ownership moderates the impact of ROA on PBV & Moderate & Accepted \\
\hline CSR does not mediate the effect of ROA on PBV & Not mediating & Rejected \\
\hline CSR mediates the effect of DER on PBV & Mediate & Accepted \\
\hline CSR mediates the effect of SIZE on PBV & Mediate & Accepted \\
\hline
\end{tabular}

Based on the test in hypothesis 1 the results are that profitability has a positive and outstanding impact on CSR. Thus hypothesis 1 is accepted. This statement is evident from the value of the regression coefficient possessed by ROA on CSR with a positive direction of 0.111 and an outstanding value of 0.001 where it has less significance rate of 0.05 . therefore the profit gain (ROA) has a positive and outstanding impact on CSR. This means that the higher the value of ROA will increase the CSR activities of manufacturing companies. ROA is reflected in the number of profits obtained by corporate, where the higher profits obtained by the enterprise, it shows that the company is profitable. Companies with high profitability are due to the existence of good work performance so that it shall provide an effect for the increasing size of the corporate's resources where the company will get a lot of public attention.

The company will make CSR disclosures more broadly so that the existence of the company can be accepted by stakeholders to ensure the enterprise withstand. The results of the study are in accordance with the results of Nurizza's study (2017), Anak Agung \& Ni Gst. Putu (2018), Ni Ketut \& Ida Bagus (2016), Meita (2015) which states that profitability (ROA) has a positive and outstanding impact on Corporate Social Responsibility (CSR). Based on the test on the second hypothesis shown the results that influence (DER) has a positive but not considerable effect on 
CSR. Thus hypothesis 2 is rejected. This statement is evident from the coefficient value the regression owned by DER on ROE with a positive direction of 0.004 and significance value of 0.233 where the value is greater than the level significance of 0.05 . So that leverage (DER) has a positive and no effect significant impact on Corporate Social Responsibility (CSR). This means that the value of DER will reduce the disclosure of CSR of manufacturing companies, but the effect is not significant. DER has a significant positive effect.

Increasing the leverage ratio shows the company's high need for fresh funds, besides the high value of leverage also reveals the company's dependence on debt which can create risks for the survival of the company. The more frequent and increasing company leverage, the more market assumptions that conclude that companies have a high dependence on debt and the higher the risk of investment. Increasing debt position is considered as a step back for management because it will affect the existence of the company and enlarge the company's risk of experiencing distress has triggered negative sentiment which has led to a decline in the disclosure of Corporate Social Responsibility (CSR) in manufacturing enterprises on the Indonesia Stock Exchange. Agency theory explains that the more the level of leverage will reduce the level of disclosure of CSR carried out by the company so as not to be the spotlight of debt collectors (debtholders). The outcomes of this study are in line with the research's outcomes from Nurizza et al., (2017) which states that Leverage (DER) has a positive and there is no outstanding effect on Corporate Social Responsibility (CSR).

The test outcomes on hypothesis 3 state that SIZE significantly positive effect on CSR, then hypothesis 3 is accepted. These results are evident from the SIZE regression coefficient with a positive direction amounting to 0.012 and a significance rate of 0,000 where the value itself is far smaller compared to the outstanding level of 0.05 . Firm size (SIZE) has a positive effect significantly towards Corporate Social Responsibility (CSR) means that any increase that occurs in the company's measurement or the whole assets owned by the CSR activities carried out by the company will also be more widespread and increasing. The size of the company is reflected in the size of the company's total assets, where the high number of assets owned provides evidence of the company's reliability. Besides that, companies with large assets have good working stability and able to generate higher profits because of the many resources owned. This is related to agency theory, where big companies with greater organizational costs will disclose wider information to reduce the agency's spent. In addition, large companies are issuers that are widely highlighted, greater disclosure is a reduction in political costs as a manifestation of corporate social responsibility (Sembiring, 2005). The outcomes of the study are in accordance with the results of research conducted by Ni Ketut \& Ida Bagus (2016) which stated that the company's measure has a positive and significant impact on Corporate Social Responsibility (CSR).

Based on the hypothesis 4 testing states that CSR positive and significant effect on PBV, then hypothesis 4 is accepted. Thing This is evident from the results of the CSR regression coefficient with a positive direction of 1.969 with a significant point of 0.004 where the point is much smaller than 0.05 . It was concluded that CSR had a positive positive effect on PBV. This statement means that the wider the disclosure of CSR by the company will increase the value of the company. Disclosure of CSR can increase firm value because stakeholder theory emphasizes that companies must disclose information CSR activities as a form of corporate responsibility towards parties stakeholders affected by the existence of the company (Chairiri and Ghozali, 2007) Not only increases the value of the enterprise, but it will gain a reputation and existence that are good in the eyes of the community with the support of these CSR activities. The results of this study are in accordance with the research from Ayu \& Suarjaya (2017) which mentioned that CSR has a positive and outstanding impact effect on firm value (PBV).

Based on the hypothesis 5 testing states that ROA positive and significant effect on PBV, then hypothesis 5 is accepted. This is evident from the regression coefficient outcomes of ROA with a positive direction of 6.476 with an outstanding value of 0,000 where the value is much smaller than 0.05 . Then it was concluded that the profit gain (ROA) has a remarkable positive effect on firm value (PBV). The statement has a meaning that any increase that occurs in profitability is the value of the company that will increase as well and vice versa. ROA has a positive and outstanding effect on firm value. ROA as a reflection of the company's capability to generate profits from its own capital. ROA indicates how much profit the investor will receive, so investors will be more interested in companies that have high returns. This result is in line with theoretical signaling where when ROA increases it is considered a signal for investors that good prospects are coming in. The increasing potential profit of the company will increase investor confidence in the demand for shares so resulting in high stock prices which also impact on the increase of enterprise's value. The outcomes of the study are in accordance with the results of the study from Dewi \& Wirawati (2018) which states that the profit gain (ROA) has a positive and outstanding effect on firm value (PBV). 
Based on the hypothesis 6 testing obtained the results that Leverage (DER) has no outstanding negative impact on firm value (PBV), therefore hypothesis 6 is rejected. This is evident from the regression coefficient of DER with a negative direction of -0.194 with a remarkable rate of 0.725 where the rate is more than 0.05 . It shows that the level of low and high leverage does not give any impact on the corporate's value. By considering this matter, it shows that investors will not respond to management decisions in addition to debt. The outcomes of the study are in accordance with the research from Hidayah (2014) with Nurminda et al.,(2017), namely leverage has a negative effect and but it does not have the significant impact on firm value (PBV).

Based on the hypothesis 7 testing obtained the outcomes that the measurement of the company (SIZE) has a remarkable positive effect on firm value (PBV), then hypothesis 7 is accepted. This is derived from the regression coefficient value SIZE with a positive direction of 0.158 with an outstanding value of 0,000 where the value is a way smaller than 0.05. SIZE has a positive effect significant to PBV which means that the total increases assets or size of the organization, the value of the company will also increase. The size of the organization has a positive and remarkable effect on PBV. Large companies are measured by the number of assets they have in which large companies have good operational performance and are considered established. This is according to the signaling theory where the increasing reliability of the company is interpreted as a positive signal for investors to consider that the enterprise has good prospects in the future. Increasing investor confidence and interest will result in rising stock prices which ultimately increases the rate of the enterprise. The outcomes of the study are in accordance with the research outcomes from Pramana \& Mustanda (2016) and Khumairoh et al., (2016) which stated that size of the company has a significant positive effect on firm value.

The result in testing hypothesis 8 had shown that institutional proprietorship which use to be a moderate variable was, in fact, cannot moderate or strengthen the effect of ROA on CSR, thus hypothesis 8 is rejected. This is evident from the regression coefficient value of ROA * INST with a positive direction of 0.003 with an outstanding point of 0.291 where the rate is greater compared to 0.05 . Based on the study conducted it can be concluded that Institutional Ownership is not able to moderate or strengthen the relationship between ROA on CSR. Companies with Institutional ownership do not necessarily get strict and professional supervision by the owner's institution to raise the value of the company. Thus, Institutional Ownership cannot build up the impact of ROA on Corporate Social Responsibility.

In hypothesis 9 testing had shown that organizational ownership which acts as a moderating variable can moderate or strengthen the influence of profitability (ROA) on firm value (PBV), then hypothesis9 is accepted. This is evident from the regression coefficient value of ROA * INST with a positive direction of 0.065 with an outstanding value of 0.048 where the value is below 0.05 . Institutional proprietorship is one of among other factors which may affect the corporate achievement. The right of possession on Enterprise by the institutional investor will push the increased of maximum supervision the performance of management because share ownership represents a source of power that can be used to support or vice versa to management performance. The greater the proprietorship of financial organizations, the greater the power of voice and the encouragement of financial organizations to supervise the management and consequently will provide a greater impetus to optimize the grade of the enterprise so that enterprise's profit gain shall also rise.

In hypothesis 10 test the results that CSR as an intervening variable cannot mediate the impact of ROA on enterprise value (PBV), then hypothesis 10 is rejected. This is obtained from the results of the Sobel test where t count is smaller than $t$ table $(0.08<1.65)$. This means that profitability cannot increase firm value supported by CSR activities done by the company. The results of this study are in accordance with the results of Agung (2018), Ketut \& Bagus (2016), Nurizza (2017) which states that CSR cannot mediate the impact of ROA on enterprise value.

In the hypothesis 11 test the results show that CSR as an intervening variable can mediate the impact of leverage (DER) on firm grade (PBV), then the hypothesis 11 is accepted. This is obtained from the results of the Sobel test where $t$ count is smaller than $t$ table $(5.50<1.65)$. The amount of the debt to equity ratio reflects the high debt used by the company to fund its assets. While the high debt will increase the burden and risk borne by the company. But the magnitude of the company's burden due to the use of debt does not have an outstanding effect on the decline of profitability in manufacturing companies in 2013-2017. Therefore, CSR is able to mediate the influence of leverage (DER) on firm value. Besides that, it can also be concluded that high and low debt does not have an effect on the grade of the company through profits obtained.

Based on hypothesis 12 shows that CSR as an intervening variable successfully mediates the influence of firm size on firm value (PBV), then hypothesis 12 is accepted. This is evident from the value of the Sobel test where the grade of $t$ count is greater than the grade of $t$ table (5.57> 1.65). The results of this study conclude that Manufacturing 
companies in the Indonesia Stock Exchange can increase the value of their company by increasing the size of the company or the whole assets owned. By increasing assets, the company can also increase the profit generated because of the abundance of resources owned. High profitability will increase investor confidence so that it can increase the company's stock price. Thus indirectly measures of the company can increase the company's point through its benefits.

\section{Conclusion}

For a company, based on results of the study, it is known that partially the independent variable which has the highest coefficient value and most significant influence in determining the Price to Book Value is Return On Assets. The coefficient value of ROA is 6.476 and significance value of 0.000 at a significant level of 0.05 . Furthermore, the independent variable partially has the second major influence after ROA is CSR which has a coefficient point of 1.969 and a significant point of 0.004 at a significance level of 0.05 . After that, the company's measured with a coefficient value of 0.158 and an outstanding value of 0.000 . Furthermore, partially the variable that contains the least influence on Price to Book Value is leverage (Debt to Equity Ratio) where this variable has a coefficient value of 0.126 with an outstanding value of 0.002. Thus the factor that is quite effected on the value of the company is the profitability that the company has successfully obtained. Therefore, it is expected that the management of the company can increase its net profit. Because high profitability will provide an indication of good company prospects, therefore, it can attract investors to raise the demand for their shares. Furthermore, increasing stock demand will cause the company's value to increase.

For prospective investors, you can use the results of this study as a reference for consideration before deciding to invest in order to get results in accordance with expectations. Referring to the results of the study, it was found that the factors that most influence the value of the company are Return On Assets (ROA) and Corporate Social Responsibility (CSR). So that it is expected that investors and prospective investors from now on not only use the company's profitability in considering investment decisions.

The results of this study should be interpreted with caution because of the limitations. First, this study only tests the relationship between firm value improvement strategy, corporate social responsibility, and institutional ownership and does not establish any causal relationship between them. Corporate social responsibility can influence firm value improvement as well as be influenced by it. Second, many factors can influence management decisions to focus on corporate social responsibility, such as moral obligations, government requirements, and maintaining good reputation and sustainability, which are not directly discussed in this study. Therefore, future research that examines the relationship between firm value improvement strategy, corporate social responsibility, and institutional ownership should discuss the changes in public opinion, development of moral values and social standards about business roles.

\section{References}

Ayu, D. P., \& Suarjaya, A. A. G. (2017). The Effect of Profitability on Corporate Social Responsibility as a Mediation Variable in Mining Companies. E-Journal of Management of Unud, 6(2).

Cecilia, \& Rambe, S. (2014). Analysis of the Effect of CSR, Profitability, and Firm Size on the Value of Go Public Plantation Companies in Malaysia, and Singapore. Thesis at the University of North Sumatra.

Chairiri, A., \& Ghozali, I. (2007). Accounting Theory. Faculty of Economics: Diponegoro University Semarang.

Chang, K., Shim, H., \& Yi, T. D. (2019). Corporate social responsibility, media freedom, and firm value. Finance Research Letters, 30, 1-7. https://doi.org/10.1016/j.frl.2019.03.019

Chen, L., \& Shun, Y. C. (2011). The Influence of Profitability on Firm Value with Capital Structure as The Mediator and Firm Size and Industry as Moderator. Investment Management and Financial Innovations, 8(3).

Cowen, S. S., Ferreri, L. B., \& Parker, L. D. (1987). The impact of corporate characteristics on social responsibility disclosure: A typology and frequency-based analysis. Accounting, Organizations and Society, 12(2). https://doi.org/10.1016/0361-3682(87)90001-8

Deegan, C., Rankin, M., \& Tobin, J. (2002). BHP Examination of the Corporate Social and Economic Disclosure from 1983-1997 a Test of Legitimacy Theory. Accounting, Auditing and Accountability, 15(3), 312-343.

Dewi, A. A. A. T. W., \& Wirawati, N. G. P. (2018). Effect of Profitability on Corporate Values with Corporate Social Responsibility as an Intervening Variable. Udayana University Accounting E-Journal, 22(2).

Elvina, N., et al. (2016). Effect Analysis of Managerial Ownership, Institutional Ownership, Leverage on Disclosure of CSR in Manufacturing Companies. University of Riau Thesis. 
Farshid, N., \& Vic, N. (2006). Institutional ownership and corporate value. Managerial Finance, 32, 247-256.

Ghozali, I. (2011). Application of multivariate analysis with the IBM SPSS program. Semarang: Diponegoro University Publishing Agency.

Hadi, N. (2011). Corporate Social Responsibility. Yogyakarta: Graha Ilmu.

Hidayah, N. (2014). The Effect Of Company Characteristic Toward Firm Value In The Property And Real Estate Company In Indonesia Stock. Exchange International Journal of Business, Economics and Law, 5(1).

Isnaini, N. A. (2017). Influence of Company Characteristics on Corporate Values: Corporate Social Responsibility as an Intervening Variable. Journal of Accounting Science and Research, 6(2).

Khajar, I., Hersugondo, H., \& Udin, U. (2018). Antecedents and Outcomes of Corporate Governance: Evidence from Indonesia. European Research Studies Journal, 21(4), 480-492.

Khan, M., Serafeim, G., \& Yoon, A. (2016). Corporate sustainability: First evidence on materiality. The Accounting Review, 91(6), 1697-1724. https://doi.org/10.2308/accr-51383

Khumairoh, et al. (2016). Effect of Leverage, Firm Size, Profitability on firm Values. Shariah Paper Accounting FEB UMS.

Lev, B., Petrovits, C., \& Radhakrishnan, S. (2010). Is doing good good for you? How corporate charitable contributions enhance revenue growth. Strategic Management Journal, 31(2), 182-200.

Maiyarni, R., et al. (2014). Effect of Profitability, Firm Size, Liquidity, and Leverage on Disclosure of Corporate Social Responsibility (CSR) in LQ-45 Companies listed on the Stock Exchange for the Period 2009-2012. Journal of Accounting Horizons, 6(1).

Nurminda, A., Isynuwardhana, D., \& Nurbaiti, A. (2017). The Influence of Profitability, Leverage, and Firm Size on Firm Values (Study on Manufacturing Companies of the Goods and Consumption Sub-Sector Registered on the Indonesia Stock Exchange Period 2012-2015). e-Proceeding of Management, 1, 542-549.

Retirement, J. (2010). Analysis of the Effect of Profitability, Size and Leverage on CSR in Companies listed on the IDX. Thesis of the Faculty of Economics, Diponegoro University.

Rezaee, Z., Dou, H., \& Zhang, H. (2019, May). Corporate social responsibility and earnings quality: Evidence from China. Global Finance Journal, 100473. https://doi.org/10.1016/j.gfj.2019.05.002

Rindawati, M. W. (2015). Effect of Profitability, Firm Size, Leverage and Public Ownership on Disclosure of Corporate Social Responsibility (CSR). Journal of Accounting Science \& Research, 4(6).

Sari, M. R. P. A. (2016). The Effect of Profitability, Firm Size and Leverage on the Value of Transportation Companies. Journal of Accounting Science and Research, 5(9).

Sembiring. (2005). Corporate Characteristics and Disclosure of Social Responsibility: Empirical Study on Companies listed on the Jakarta Stock Exchange. Paper Presented at the National Accounting Seminar, Solo.

Servaes, H., \& Tamayo, A. (2013). The impact of corporate social responsibility on firm value: The role of customer awareness. Management Science, 59(5), 1045-1061. https://doi.org/10.1287/mnsc.1120.1630

Siddik, H. M. (2017). Analysis of the Effect of ROE, Current Ratio, Size and Institutional Ownership on Firm Values with Capital Structure as Intervening Variables (Study of Real Estate Companies listed on the Stock Exchange in 2011-2016). Diponegoro of Journal Management, 6, 1-15.

Swandari, F., \& Sadikin, A. (2016). The Effect of Ownership Structure, Profitability, Leverage, and Firm Size on CSR. Binus Business Review, 7(3), 315-320. https://doi.org/10.21512/bbr.v7i3.1792

Triagustina, L., Sukarmanto, E., \& Helliana. (2015). Effect of Return on Assets (ROA), Return on Equity (ROE) on Firm Values. Accounting Proceedings (pp. 28-34).

Wihardjo, D. S. (2014). Analysis of factors that influence the value of study companies in Manufacturing companies listed on the Indonesia Stock Exchange in the year 200-2011. Undergraduate Thesis, Faculty of Economics and Business, Diponegoro University.

Yunanto, A., Daryono, W. S., Ghozali, I., \& Udin. (2017). The Value Relevance on Retail Trade Industry: Evidence from Southeast Asian Countries. International Journal of Civil Engineering and Technology, 8(12), 519-526.

Zulvina, F., et al. (2017). Ownership Structure, Independent Commissioner, and Corporate Social Responsibility. Research Journal of Finance and Accounting, 8(22). 